\title{
As marcas da interseccionalidade nas trajetórias de três acadêmicas negras
}

\section{The marks of intersectionality in the trajectories of three black scholar women}

\author{
Juliana Araújo Santos (orcid.org/0000-0002-3746-5202)' \\ Sheila Ferreira Miranda (orcid.org/ 0000-0002-3144-6254) 2
}

\begin{abstract}
Resumo
Nesta pesquisa, propomo-nos a repensar o lugar da mulher negra em ambientes acadêmicos, os quais, supostamente, constituem espaços de produção democrática de saberes e de profissionais compromissados com a realidade social e suas fissuras. Por meio do método da história oral temática, foram entrevistadas três professoras universitárias negras, na busca da compreensão dos significados assumidos e conferidos às transformações experenciadas ao longo de suas vidas escolares e acadêmicas. Desse modo, procuramos compreender as características e contradições do processo identitário dessas mulheres e perceber de que modo as marcas interseccionais de raça, gênero e classe perpassam suas existências e seus projetos políticos; orientadas, sobretudo, pela ética da emancipação.
\end{abstract}

Palavras-chave: Identidade. Raça. Gênero. Classe. Professoras universitárias.

\begin{abstract}
In this research, we propose to rethink the place of black women in academic environments, which supposedly constitute spaces for democratic production of knowledge and professionals committed to social reality and its fissures. Through the method of thematic oral history, three black female university professors were interviewed, in an attempt to understand the meanings assumed and given to the transformations experienced throughout their school and academic lives. In this way, we seek to understand the characteristics and contradictions of the identity process of these women and to understand how the intersectional marks of race, gender and social status permeate their existences and their political projects; guided, above all, by the ethics of emancipation.
\end{abstract}

Keywords: Identity. Race. Gender. Working class. Professors.

\footnotetext{
${ }^{1}$ Universidade Federal de São João del-Rei, São João del-Rei, Brasil. E-mail: juliana.arsantos@hotmail.com

${ }^{2}$ Universidade Federal de São João del-Rei, São João del-Rei, Brasil. E-mail: sheilamirandaufsj@gmail.com
} 
"Com o sangue de quem foram feitos seus olhos?"

Donna Haraway

Todo conhecimento produzido até hoje, ao qual, supostamente, se tem acesso foi fruto de muitos esforços, lutas e mortes de pessoas que acreditavam em ideais destoantes de sua época e afirmavam posições políticas. Porém, nenhum conhecimento diz de uma verdade universal. Todo saber é localizado e envolve um grupo oprimido ou opressor em suas relações de poder. O acesso ao ensino sempre foi uma das reivindicações dos movimentos negros no Brasil, contudo, foi só a partir da III Conferência Mundial de Combate ao Racismo, Discriminação Racial, Xenofobia e Intolerância Correlata, ocorrida em Durban no ano de 2001, que as lutas e prerrogativas desses grupos oprimidos tiveram maior visibilidade para todo o mundo. Em resposta a essas questões, foram implementadas pelo governo brasileiro as ações afirmativas para maior acesso da população negra à educação e ao ensino superior (Pires, 2014). No entanto, em que pese a existência de políticas públicas de inclusão a uma parcela correspondente a mais da metade da população total do país (53,7\%, segundo o Instituto Brasileiro de Geografia e Estatística, IBGE, em 2012), algumas universidades ainda são hegemonicamente brancas. Segundo levantamento do Instituto Nacional de Estudos e Pesquisas Educacionais Anísio Teixeira (INEP), em 2012, havia 2.416 instituições de ensino superior no Brasil (públicas e privadas), com 7.037.688 de alunos matriculados e 378.939 docentes. Desse total de professores, apenas 13,22\% são negros, ou seja, há aproximadamente 50.145 professores universitários negros no ensino superior, sendo que $33,9 \%$ desses estão em instituições públicas; a maioria é masculina $(54,43 \%)$ e, geralmente, com titulação máxima de mestre (43,09\%) (Arboleya, Ciello, \& Meucci, 2015).

Segundo Carvalho (2006), deve ser observado que as universidades, desde a sua fundação e expansão de ingresso de alunos e professores no século XX, nunca tomaram iniciativa para corrigir a exclusão racial que as caracterizava. Há um silêncio sobre o tema no próprio ambiente universitário e também sobre a sua realidade interna que configura a exclusão social, a qual reproduz e legitima a ordem social estabelecida, demarcando um racismo institucional. Quando uma docente universitária negra consegue ultrapassar barreiras históricas racistas, sexistas e classicistas, certamente se torna uma referência que 
inspira discentes negras que queiram seguir a trajetória profissional. Assim, ser uma intelectual negra num contexto social capitalista de supremacia patriarcal branca (Hooks, 1995) circunscreve lutas diárias contra diferentes tipos de opressões, naturalizadas e reproduzidas constantemente por seus pares; logo, é necessário "descolonizar a mente" para haver legitimidade. Essa mulher encarnará as relações sociais vividas, configurando, assim, sua identidade pessoal.

Nesta pesquisa, a identidade não será usada como um termo estático analisado através de parâmetros universais, rígidos e imutáveis, mas com um olhar de constante mudança e movimento em relação ao social: o ser humano como produto e produtor da própria história na sua relação com os outros, igualando-se e diferenciando-se em alguns aspectos, revelando-se no "estar sendo" ao mesmo tempo em que nega "o que não está sendo", ocultando-se em sua totalidade (Ciampa, 1987). Haraway (1995) chama a atenção para as pesquisas sob a perspectiva dos grupos oprimidos. Para a autora:

Não são posições 'inocentes'. Ao contrário, elas são preferidas porque, em princípio, são as que têm menor probabilidade de permitir a negação do núcleo crítico e interpretativo de todo conhecimento. Elas têm ampla experiência com os modos de negação através da repressão, do esquecimento e de atos de desaparição - com maneiras de não estar em nenhum lugar ao mesmo tempo que se alega ver tudo. (p. 23)

É preciso sensibilidade para captar os processos de emancipação e metamorfose dessas pessoas que fazem parte de um grupo subjugado, o qual alguns definem como "minoria". À propósito, como observa Louro (2001), essa é uma designação imprópria por se tratar de maiorias silenciosas que, ao se politizarem, convertem o gueto em território e o estigma, em orgulho. Diante do quadro brevemente exposto até então, a fim de compreender o contexto social e as eventuais forças coercitivas que atingem essas mulheres, foram entrevistadas três professoras universitárias negras, tendo como suporte metodológico a história oral temática. Dessa forma, é possível entender a complexidade de um sistema através dos recortes das vidas dessas mulheres, pois "o singular materializa o universal" (Carone, s.d., p. xx). 


\section{O sintagma identidade-metamorfose-emancipação}

Segundo Ciampa (1999), a justificativa pelo termo sintagma se deve ao fato de ser uma concepção que se define basicamente por esses três termos, o que caracteriza um "macro-conceito", ou seja, conceitos indissociavelmente articulados entre si. A identidade se caracteriza pela interação social, que se dá sempre como metamorfose no movimento histórico em direção à emancipação, de modo a tornar o homem humano de fato, em sua individualidade e coletividade, moldando sociedade e natureza como história (Kolyniak, 2005).

Faz-se oportuno destacar que o importante não é só coletar o maior número de informações acerca do sujeito, mas compreender aquilo que ele não deixa claro, o que se oculta e se mostra velado, seus significados implícitos nas vivências (Carone, s.d.). A proposta é perceber seu movimento de metamorfose, através dos diversos predicados que a sociedade espera que ele represente, como o personagem interpreta os vários papéis: repondo certos pressupostos ou os reinventando, criando novos personagens (Ciampa, 1987). A identidade é sempre processo de metamorfose cujo sentido ético é a emancipação que se concretiza através de ações políticas (explícitas ou não). Os fragmentos de emancipação podem ser impedidos através de forças coercitivas (por um poder interiorizado subjetivamente ou exteriorizado objetivamente), invertendo o processo de metamorfose, caracterizando um processo de desumanização (Ciampa, 2003).

São as atitudes do sujeito frente aos obstáculos conflitantes que a sociedade impõe que definirão o sentido ético do seu processo identitário, que será marcado ou pela heteronomia do discurso hegemônico, a qual reifica suas ações e impede a realização de projetos políticos emancipatórios; ou pela autonomia do discurso de uma coletividade que o representa e será efetivado por uma ação política de projetos que visam à emancipação de um grupo (Ciampa, 2003).

Devido a essa tensão de interesses políticos que mudam com o passar do tempo, movimentos sociais são invisibilizados e instituições de Estado não garantem equidade e justiça para a população. Essa seria a nova "intransparência" a que Habermas (1987) se 
refere, na qual o Estado se sustenta por meio de uma sociedade produtiva (que utopicamente se esperava emancipar através do trabalho) que não consegue visualizar possibilidades a posteriori de uma vida coletiva melhor e menos violenta. Logo, para que o sentido ético da identidade seja alcançado, o primeiro passo deve ser a prática efetiva da democracia, cujo objetivo seja a construção de um poder baseado na solidariedade e abandono da violência, através da ação comunicativa. Esta se define pelo respeito à alteridade e à diferença e a resolução de conflitos orientada por negociações multilaterais garantidas pelo Estado de Direito, na qual nenhum individuo, seja cidadão comum ou presidente, está acima da lei (Ciampa, 2003).

\section{Da democracia racial ao racismo acadêmico}

Durante muito tempo, o movimento militante foi invisibilizado e silenciado em suas lutas e reivindicações pela hegemonia que, baseada na ideologia do branqueamento e no mito da democracia racial, atuou sistematicamente para ofuscar a problemática da sociedade brasileira em sua relação com o contingente de pessoas negras.

A ideologia do branqueamento atua como resultado de ideias provenientes do processo de colonização brasileiro, no qual haveria uma suposta superioridade racial daqueles considerados brancos sobre os negros. Em decorrência dessa herança, permeia no imaginário social brasileiro a ideia de que a assimilação de elementos da cultura vigente garantiria um status diferencial ao negro, isto é, "embranquecer-se" e negar os elementos afro do próprio processo identitário com o fito de ser incluído (Munanga, 2004).

Já o mito da democracia racial surge inicialmente como ideal de pensamento do movimento intelectual hegemônico do início do século XX, sobretudo na figura de Gilberto Freyre, a partir do clássico "Casa Grande \& Senzala". Essa linha de pensamento defendia o fato de que existiria no país uma igualdade de relações entre todas as raças e de que o "mulato" seria o ícone representativo dessa suposta harmonia. Com o passar dos anos, esse ideal se tornou um mito (uma crença que torna invisível a realidade), que gerou um discurso ideológico de democracia e da não existência do preconceito no país (Miranda, 2011 a). O 
ideal da democracia racial é um mecanismo social de dissimulação mediado por um aparente tratamento cordial que nega a existência de qualquer tipo de discriminação racial. Apesar dele, as pessoas desenvolvem um imaginário cujas características dos fenótipos atuam como referências para o preconceito manifesto, muitas vezes, de forma velada.

O resultado desses dois fenômenos é denominado racismo à brasileira (Ferreira, 2002). Ao compreendermos que ambas ideias continuam tendo ressonância nas vidas de negros e não-negros, podemos perceber, através da ideologia do embranquecimento, que a ideia impressa é de que "embranquecer" é a solução para a ascensão social. Daí surge o preconceito, porque não admitimos resquícios da cultura afro como algo positivo no processo de trânsitos da diáspora. Ao mesmo tempo, o mito da democracia racial imprime a ideia de que no Brasil não há preconceito. A partir disso, somos influenciados pela concepção de que "todos somos mestiços" e, portanto, de uma situação de aparente igualdade racial. Um dos resultados desta dinâmica é a vergonha de admitir atitudes discriminatórias as quais continuam vigorando por influência da ideologia do branqueamento (Miranda, 2011a). Todo esse contexto gera ambiguidade e conflito no pensamento dos brasileiros, porque o preconceito racial existe, mas não é abertamente afirmado; porque temos "preconceito de ter preconceito". Logo, o preconceito se manifesta muitas vezes, encoberto por frases educadas, piadas e insinuações (Ferreira, 2002).

A partir desse pensamento que perpassa as relações cotidianas, é possível manter uma estrutura racista, sem muitas represálias, através de ações "sutis" (e não menos violentas) que são naturalizadas e reproduzidas pelas pessoas, e, dessa forma, inibem as políticas públicas voltadas para a eliminação das desigualdades. Esse argumento sustenta o que Munanga (2004) define como um modelo racista universal, no qual há negação absoluta da diferença e sugestão de uma homogeneidade que não é explícita, mas que poderia se realizar pela miscigenação e apropriação cultural.

A democracia racial tem raízes históricas e é marcada e ilustrada pela leitura de Casa Grande e Senzala, de Gilberto Freyre. Nesse texto, o autor demonstra, por meio de documentos históricos e com "considerável licença poética", o quanto a população brasileira é híbrida, em que índios americanos, africanos e portugueses se entrecruzaram através de diversas trocas genéticas e culturais (Fry, 2002). Percebe-se a negação da existência de 
qualquer tipo de preconceito devido à miscigenação. O valor antirracista é compartilhado em qualquer estrato social brasileiro. De acordo com esses pressupostos e naquele momento político, afirmar a inferioridade de uma raça poderia gerar a segregação, o que seria um dificultador entre as relações sociais no Brasil.

O racismo, no contexto acadêmico, ainda é pouco comentado. Todavia, esse meio se constitui através da reprodução do racismo silencioso, que pode ser tão ou mais doloroso que a ação explícita de discriminação. Há poucas referências e reconhecimento de intelectuais negros e seu protagonismo no meio acadêmico brasileiro, o que, segundo Carvalho (2006, p. 91) “[...] é um forte indício da resistência da classe acadêmica de enfrentar-se com sua condição racial privilegiada".

\section{Sobre as marcas que interseccionam opressões}

O reconhecimento de que as experiências das desigualdades podem e muitas vezes são perpassadas por uma série de outras subordinações significa compreender o sujeito em seu contexto político, econômico, histórico e social. As relações de raça são vivenciadas de forma diferente ao se acrescentar o gênero, classe, regionalidade ou orientação sexual, por exemplo (Marcondes, 2013).

As marcas de submissão são incorporadas no cotidiano das pessoas de modo a naturalizar barreiras que limitam oportunidades de trabalho, ascensão no emprego, percepção para salários desiguais, além de proporcionar acesso, muitas vezes desqualificado, a serviços do Estado, tais como saúde, educação e justiça, reverberando de forma permanente na inserção social dessas pessoas (Marcondes, 2013). Essas pessoas são identificadas por uma força que exclui, a qual, ao ser naturalizada pela sociedade, é reiterada pela prática e pelos efeitos de discurso. Por não se ajustarem aos princípios hegemônicos, esses corpos abjetos são eliminados de diversos contextos sociais. Vidas que não são consideradas vidas, mas que, ao entender esse processo de exclusão, podem criar mecanismos de resistência e ressignificar as práticas sociais (Butler, 2007). 
Quando uma mulher negra segue a carreira acadêmica, ela ressignifica um lugar que não the é atribuído como natural, mas como algo "acima do previsível", o qual, muitas vezes, é questionado por colegas de trabalho e alunos em termos de sua capacidade e legitimidade (Santos, 2003). Ademais, o ofício acadêmico demanda certo isolamento para o mergulho no pensamento e na escrita, o que exige um malabarismo dessas mulheres para atender à demanda de suas famílias, renunciando ao convívio dos seus (Hooks, 1995). Atender às demandas de seus pares e, ao mesmo tempo, trabalhar, significa encarar uma dupla ou tripla jornada. Tal situação é ainda carregada de culpabilizações, uma vez que o racismo e sexismo dificultam para elas, mulheres negras, conseguir um lugar no mercado de trabalho (Marcondes, 2013).

Scott (1995) pontua que o gênero é uma das primeiras formas de significar as relações de poder baseado nas distinções dos corpos através do sexo biológico, sendo a sociedade que projeta um fantasma na sexualidade, e, não, a sexualidade que produz fantasmas na sociedade. As marcas da raça, gênero, classe, orientação sexual, podem ser formas de a sociedade projetar fantasmas que oprimem e subjugam corpos, mas também podem ser motivo para lutas por direitos que visem igualdade e equidade.

\section{História oral temática: revivendo o passado elaborado no presente}

A fim de captar o processo identitário destas mulheres, professoras universitárias negras, com relação à incidência da intersecção raça, classe e gênero em suas trajetórias escolares e acadêmicas, foi utilizado como aporte metodológico a história oral temática. Esse método permite, por meio de um recorte temático, que o sujeito narre e expresse o significado de suas experiências, trazendo sua subjetividade nas próprias interpretações de recordações. É característica da história oral fazer emergir fatos da vida da pessoa que foram cruciais para formação de sua identidade, sobre a percepção da própria situação sócio-histórica com relação às injustiças sofridas na pele, privilégios, lacunas e silêncios (Meihy, 1996).

Além de a memória ser um fenômeno individual e possibilitar o acesso aos elementos constitutivos da identidade, ela também deve ser entendida como um elemento 
coletivo e que diz do âmbito social, o qual é construído coletivamente e sujeito a variações, hesitações e transformações contínuas. O eco da história desses indivíduos permite privilegiar a análise de grupos minoritários e oprimidos, sobretudo por meio das memórias subterrâneas - que se opõem à "memória oficial”, a qual muitas vezes tem um caráter uniformizador e opressor (Pollak, 1989).

A fim de privilegiar a fala deste grupo que ainda é uma minoria numérica, professoras universitárias negras, foi realizada a primeira abordagem, que se deu através de contatos por e-mail. Depois de realizados os contatos preliminares para devida apresentação do projeto, foi confeccionado um roteiro flexível de acordo com as categorias temáticas da pesquisa e a apresentação do termo de consentimento livre e esclarecido. Em prosseguimento, entrevistamos as três professoras universitárias. O critério de seleção dessas mulheres foi a autoatribuição identitária como negra. O local das entrevistas foi escolhido pelas participantes, de acordo com suas conveniências e disponibilidades. De posse das entrevistas, as transcrições foram enviadas às colaboradoras para conferência. Diante do potencial analítico das três entrevistas, nenhuma foi descartada. Além disso, todos os nomes utilizados são fictícios, escolhidos pelas autoras com o consentimento das participantes.

\section{Mercedes: aprendendo a criar mecanismos de superação}

Mercedes é fenotipicamente negra, tem 59 anos, há 20 leciona; atualmente trabalha numa instituição pública. Teve acesso a boas escolas desde o ensino básico até o nível superior; graduou-se num curso da grande área de ciências sociais aplicadas, possui mestrado, doutorado e se encaminha para o segundo pós-doutorado. Hoje, consciente de sua condição racial e do racismo permeado nas relações sociais, relata que, quando jovem, não percebia se passava por situações de preconceito, mas não nega a possibilidade que as tenha vivido sem significá-las.

Logo em sua infância, ela teve referências de pessoas negras que ascenderam economicamente, porém, em seu círculo de amizades, havia mais pessoas brancas do que 
negras. Após se graduar, ingressou rapidamente no mercado de trabalho, atuando em diversos ramos de sua área nos quais obteve reconhecimento. No entanto, nem todos os processos seletivos que realizou eram imparciais: ela se recorda que, quando jovem, fez diversas provas para ser aeromoça e, mesmo tirando notas altas e se destacando, nunca era o suficiente para sua contratação. Incrédula, questiona-se o porquê de tantas exigências:

Eu tentei ser várias, várias vezes, até o ponto do meu pai falar comigo: - Você não entendeu porquê você não passa? - Eu tirava 10 em tudo e eles sempre pediam mais e mais e mais [...] Aí eu falei: - Pai, eles dizem que eu vou ter que esperar; por que eu vou esperar até agora? Aí ele falou: - Você não entendeu ainda, não? Você já viu alguma aeromoça negra?" Naquela época, falei: - Não. - Então, presta atenção!

Se descobrir negra é mais que constatar o óbvio; é uma categoria que se desvela através de experiências, experiências que massacram a identidade, submetem o indivíduo a exigências e o impelem a expectativas alienadas (Souza, 1983). Contudo, essas mesmas experiências geram possibilidades de recriar novas formas de vida, resgatando sua história. Foi isso que Mercedes fez logo após trabalhar durante 11 anos em uma empresa privada: "Eu sabia da dinâmica da empresa, jamais iam me dar a chefia da assessoria, a uma negra, eu tinha consciência disso [...] eu tava com certo enfado daquela posição e eu queria mais".

Ela queria novos horizontes. Foi então que surgiu a oportunidade de um mestrado. Mercedes percebe que o trabalho como assessora na empresa, ao mesmo tempo que a tornava "reconhecida" diante da sociedade, reificava-a, tornando-a "objeto" do sistema capitalista. Dessa forma, seu emprego não abria possibilidades futuras de uma vida mais digna e menos opressiva (Habermas, 1987). E é na continuação dos estudos que ela vislumbra a transformação e a legitimação de sua identidade como mulher negra, na tentativa de sanar conflitos das expectativas sociais contraditórias que estava vivenciando (Ciampa, 2002).

“[...] eu sempre tive o estudo como uma forma de válvula de escape para mim".

A vida intelectual sempre foi como um refúgio, um abrigo, no qual ela podia ter a percepção de atuar sobre seu contexto e poder construir sua própria identidade subjetiva (Hooks, 1995). O estudo é estimado, não pelo status ou reconhecimento que traz consigo, 
mas como meio de intensificar a sobrevivência e o prazer de viver: "Eu era uma aluna que eu não tirava...8, então eu era bem quista, eu era CDF".

Assim, a busca pelo acesso ao conhecimento em toda sua trajetória fazia sentido, pois nele não havia subordinação, inferiorização e opressão. Recorda-se que, entre os amigos, nunca era apresentada como apenas Mercedes, mas como "Mercedes que trabalha na empresa X", "Mercedes que é pós-doutora", sempre apresentada com um complemento para legitimar sua intelectualidade e status social; ela não era apenas "Mercedes-amiga", mas a "Mercedes-que-tem-títulos". A identidade pressuposta que ela adquiriu com o trabalho/estudos é uma parte dela em seu contexto, porém, ela é materializada pelos amigos como uma totalidade. Ao tomar essa parte como todo, há objetificação pelo caráter atemporal formalmente atribuído a sua identidade, o que confunde seu comparecimento frente aos outros com a expressão de sua totalidade (Ciampa, 1984).

Com 23 anos, Mercedes decidiu cuidar da sua saúde mental. Começou a fazer terapia e, em sessões de grupo, percebeu a violência da discriminação que sofria. Segundo Habermas (1987), a autorreflexão de uma situação torna possível a comunicação entre as pessoas, o que faz com que suas interpretações frente a um fato sejam mais ponderadas. $\mathrm{O}$ sentido de tais interpretações pode conformar interesses emancipatórios ou libertadores. A ação comunicativa, conceito do mesmo autor, permite conexão entre os indivíduos e a compreensão das situações conflituosas; nesse caso, compreendemos que o contexto da sessão de terapia em grupo permite que, através da ação comunicativa, as pessoas sejam reconhecidas intersubjetivamente e aceitas através dos seus discursos.

A fala não significa uma ação vazia, mas uma reivindicação que se pretende válida. Essa relação entre os indivíduos os torna sujeitos quando respeitados em seus argumentos, questionando normas e práticas socialmente impostas (Miranda, 2014). Nesses encontros com outras pessoas, ocorreu seu primeiro contato com a intersecção gênero, orientação sexual e raça:

A primeira vez que eu vi falar de mulher lésbica, que era negra e lésbica, essa mulher sofria tudo que vocês possam imaginar, NEGRA E LÉSBICA?! NÃO! AH, DÁ UM 
TIRO NA CABEÇA! Eu olhava pra ela, eu não acreditava, ela não podia, ela tinha dois olhos, igualzinho a mim; ela tinha os mesmos medos que eu, ela era gente como eu! A partir destas reflexões nos encontros terapêuticos, Mercedes começava a perceber a variabilidade de discriminações pelas quais as pessoas podem passar, além da raça. Segundo ela: "Meus pais me deram a vida; ele [o terapeuta] me deu a consciência de ser humano, de mulher negra, e ele é branco, tá?"

Mercedes trabalhou 15 anos em uma instituição de ensino privada. Ela relata um episódio no qual ela corrigia uma atividade avaliativa em roda com os alunos e, ao explicar uma questão para a aluna que não havia computado os pontos, usou o vocativo "minha filha":

Ela ficou muito, muito indignada, e eu vi que a indignação dela foi porque eu tinha dito "minha filha", e ela, uma menina, eu me lembro, era muito clarinha e tinha os olhos verdes, [...] ela falou "MINHA FILHA, NÃO!" falou colocando o dedo em riste pra mim e tudo "MINHA FILHA, NÃO, QUE EU NÃO SOU SUA FILHA, QUE EU TENHO FAMÍLIA!"

Mercedes ficou em estado de choque e boa parte da turma percebeu que houvera um excesso por parte da aluna. Após esse episódio: "Eu fui pra casa. Saí da sala e comecei a chorar; aí eu comecei a chorar e chorei a noite inteira, chorei, chorei muito".

Ser negro é ser violentado de forma constante, contínua e cruel, sem pausa ou repouso, por uma dupla injunção: a de encarnar o corpo e os ideais de Ego do sujeito branco e a de recusar, negar e anular a presença do corpo negro (Souza, 1983, p. 2-2).

Há várias formas de expressar o racismo, e a rejeição verbal é uma delas. O comportamento agressivo da aluna demonstra o quanto a discriminação na sociedade ainda é daninha. A aluna faz da sua branquitude verbo; ao dizer que "não é filha da professora" faz um exercício, utilizando-se do seu lugar de privilégio para oprimir a professora, num discurso evidentemente violento e desumanizante que imprime a ideia de que "você nunca seria minha família" e não está qualificada para isso porque "não é branca".

Quando começou a lecionar nessa instituição, Mercedes era contratada pelo regime de hora/aula, no qual o professor não é incentivado a se envolver com outros assuntos da 
universidade que não se refiram ao ensino: "[...] eu era horista, então não se esperava de mim pesquisa".

Com o passar dos anos, ela ascendeu na carreira, fez doutorado e pós-doutorado, tornando-se professora de dedicação exclusiva da instituição. Porém, com as mudanças no cenário político, houve um grande aumento de instituições de ensino públicas que impactou diretamente a instituição particular na qual Mercedes trabalhava. Assim, cursos foram fechados e ela sabia que seria demitida: "Eu era o salário que mais impactava a universidade, eu fui a primeira a sair e ficaram os horistas pra manter os cursos até terminarem as turmas".

Foi nesse contexto que ela prestou concurso para instituição pública em que trabalha atualmente. Assim que Mercedes começou a lecionar na atual instituição, ela percebeu o quanto sua presença incomodava: "Eu entrei pós-doutora e negra, pós-doutora, a primeira mulher do curso e negra".

Ser uma intelectual negra em nossa sociedade regida pelo capital e de supremacia patriarcal branca não é algo visto como natural. É necessário contrabalancear constantemente a baixa estima imposta por ser mulher negra nas intersecções que perpassam racismo, sexismo e uma cultura anti-intelectual (Hooks, 1995). Devido à sua presença "inesperada", o sujeito negro se sente inferiorizado, isolado, e percebe o quão perversa é sua inserção no meio acadêmico (Lima, 2001). Em acordo com Habermas (1987), esses conflitos sociais internalizados e movidos para o psíquico e corpóreo do sujeito não deixam de ser extremamente nocivos e danosos: "No estágio atual do curso, há uma conjunção política que eu não sou favorecida, não! Entendeu? As pessoas me respeitam, porque não dá pra jogar no lixo 20 anos de docência...".

Mesmo fazendo parte desse ambiente individualista e competitivo no qual, nas palavras dela: "As pessoas trabalham com ego acima de tudo".

Mercedes ainda é movida por uma ética emancipatória, sonha em concretizar um projeto político: "Eu tenho um sonho que é dar aula no mestrado. Gente, eu vou ficar muito realizada de dar aula no mestrado, muito feliz".

Tendo esse mestrado como possibilidade: 
a gente [os colegas de trabalho] se reunia só pra essas brigas, essas coisas assim, agora é assim: qual que é sua temática de estudo? Sabe como é que é? Que você tá fazendo no seu projeto de pesquisa? Ah! Olha eu também... estão descobrindo coisas, sabe? Eu queria ver se a gente criava um ambiente, mais de comunidade.

A academia deveria ser um espaço que promove a humanização e a construção democrática de saberes; entretanto, apresenta-se como um lugar que sofreu invasões sistêmicas e reproduziu, no interior das relações sociais, as lógicas do funcionamento econômico e burocrático, acompanhando o pensamento habermasiano (Miranda, 2013). No entanto, há também uma subversão dessa dinâmica de poder, e surge uma possibilidade para que todos possam proferir suas próprias ideias, projetos e necessidades, serem ouvidos e se solidarizarem por iniciativa própria; por uma ideia em comum: a possibilidade do mestrado. Há uma práxis comunicativa voltada para um processo de formação discursiva da vontade (Habermas, 1987), contexto no qual o grupo de colegas, até então fragmentado, que antes se reunia para brigar, agora se integra e socializa na busca por uma possibilidade de crescimento do coletivo.

\section{Enedina: a luta através da intelectualidade e determinação}

Enedina é fenotipicamente mestiça, 29 anos, casada e, algumas semanas após a entrevista, defendeu seu doutorado. Leciona há dois anos em uma instituição na qual também se graduou, na grande área das ciências sociais aplicadas. Enedina vem de uma família de classe baixa, criada por mãe solteira que trabalhava como empregada doméstica. Sua relação com o contexto dos patrões de sua mãe era a "[...] da criança que olha o doce lá no outro [lado], que não pode pegar".

Segundo Crenshaw (2002), mulheres pobres (como a mãe de Enedina), em decorrência do desajuste estrutural de classe, veem-se obrigadas a carregar o peso da família dos outros além da própria, mantendo relações desiguais de classe marcadas pelo gênero e, nesse caso, também pela raça. Muitas vezes, Enedina acompanhava a mãe no trabalho ou ficava sozinha em casa, com tios que não tinha intimidade. Assim, encontrava 
na leitura um refúgio. Ainda que o trabalho da mãe muitas vezes privasse a filha do seu convívio, também permitiu acessos à Enedina: "Eles me davam muitos livros, livros usados, mas muitos livros. Eu lia muito, com as coisas que eles me davam, até livros didáticos também eles me passavam, romances na época, livros infantis desde criança".

O gosto pela leitura e escrita se tornariam aliados e justificativa para sua escolha profissional no futuro. Segundo a participante: "Eu sempre gostei muito de brincar de ser professora, aquela coisa toda assim, escrever e tal, aí eu decidi que eu queria fazer mestrado".

Contrariamente, a decisão por trilhar um caminho intelectual, para mulheres negras, é, muitas vezes, semelhante a uma convocação: elas são atraídas, quase empurradas para o trabalho intelectual, por forças maiores que a própria vontade individual (Hooks, 1995).

Com uma trajetória linear de graduação, mestrado e doutorado, Enedina teve experiências que a fizeram refletir sobre sua condição de mulher negra, em que a desigualdade de classe também era demarcada. Seu mestrado foi em uma instituição pública. Nessa época, Enedina se mudou e seu namorado a acompanhara. Segundo ela, seus vizinhos duvidavam disso, dizendo: "Que tá indo estudar o que... isso é mentira, tá é arrumando desculpa pra morar com aquele homem dela!".

Assim, ingressar no mundo acadêmico significou romper com a socialização sexista e racista que coloca os afazeres domésticos ou outras atividades servis como prioridade às mulheres, deixando o trabalho intelectual como secundário (Hooks, 1995).

Ela também percebe que a universidade é um lugar elitizado e que não tem representatividade de pessoas negras:

Você começa a perceber que você tá num lugar que não é pra você; e aí, assim eu percebi que eu tava num lugar que não era pra mim, tanto do ponto de vista financeiro. E até você começar a perceber as características fenotípicas de quem tá ali, né; então, assim, eu lembro: todo mundo tinha carro, isso era uma coisa naturalizada; eu, nem; tava longe assim de ter um carro!

A voz de Enedina, assim como de tantos outros negros que ingressam na carreira acadêmica, diz de uma opressão não só econômica e racial, mas de um passado histórico 
sem acessos a campos do saber legitimados, que ainda reverbera nos dias atuais (Lima, 2001). Isso é demarcado pela entrevistada em relação à pouca expressividade de contingente negro no meio acadêmico. Mesmo cumprindo todos os requisitos para estar na pós-graduação, Enedina ainda se sente deslocada: os obstáculos raciais, de classe e gênero não são vencidos; eles sempre reaparecem de maneira mais forte (Miranda, 2013).

No mestrado, segundo ela, uma das épocas mais difíceis de sua vida, a carga de leitura era extensa. Para atender às cobranças acadêmicas precisou diminuir suas horas de sono, porém, o dinheiro não dava para cobrir todos os gastos com leituras: "Tinha que pegar de um colega meu, texto emprestado. Eu lembro que eu tinha computador e impressora em casa, digitalizava o texto pra eu ler no computador e fazia marcações no Paint".

No sistema de classe da nossa sociedade, a mulher negra está claramente no fundo do totem econômico. Sua ascensão social é muitas vezes vista de maneira individualista, algo coerente com o discurso que a democracia racial prega, o qual dá ênfase à capacidade individual como a única responsável pela realização das conquistas (Souza, 1983). No entanto não é justo comparar um aluno que sempre teve acessos facilitados no sistema educacional com outro de classe baixa e escola pública, mesmo que frequentem o mesmo curso e ocupem os mesmos lugares na academia (Miranda, 2013) - como é o caso dos colegas que Enedina esperava para pedir textos ou dinheiro emprestados.

Enedina reflete que seu mestrado Ihe proporcionou grande crescimento profissional, possibilitando uma visão mais crítica acerca da sociedade. Porém, a questão racial ainda não fazia sentido para ela:

Eu nunca me vi como negra, eu nunca tive essa coisa, eu sempre fui "a morena" [...] a minha família era toda de pele mais escura que a minha. Pra eles, até hoje, eles acham que eu sou branca [...], então eu não cresci numa questão, num meio que me permitisse essa ligação com a identidade negra.

No Brasil, a classificação racial do mestiço é cromática, ou seja, fundamentada na marca e na cor da pele (os escuros são os negros e os claros são os brancos) e, não, na origem, como nos Estados Unidos. De acordo com o grau de miscigenação, o mestiço pode perpassar o limite de cor e ser considerado como "branco", jamais sendo reclassificado 
como negro, salvo quando adquire a sua própria visão ideológica (Munanga, 2004). Devido ao seu grupo primário não reconhecer Enedina como negra, sua posição política frente a isso se deu mais tarde, quando entrou no doutorado.

Seu doutoramento foi em outra instituição pública, ainda que com algumas restrições econômicas. Segundo a participante:

Academicamente, pra mim, foi fantástico [...] ele extrapolou muito essa questão do profissional pra mim, tem tudo a ver com uma questão pessoal, assim, de reflexão, sobre a própria trajetória e tal, e de começar a entender algumas coisas que você ainda não tinha clareza.

Enedina conta que, durante mestrado e doutorado, teve alguns problemas de saúde que se agravaram em decorrência das cobranças acadêmicas e da restrição econômica. Agora, com a vida mais estabilizada, ela pode se dedicar a si mesma, à saúde e realizar outros desejos, como tirar a carteira de motorista e ter seu carro próprio: "Eu ia pra [instituição pública] dar aula de ônibus, os alunos olham, acham muito engraçado, que pra eles não é muito comum".

O sujeito negro luta todo o tempo contra as estruturas de dominação. Para Enedina, a ascensão como projeto emancipatório traz consigo a prova evidente da inserção racial, a saída da marginalidade social, onde estivera enclausurada, tornando-se um instrumento de libertação econômica, social e política (Souza, 1983).

\section{Pollyanna: movendo-se através do "jogo do contente"}

Pollyanna é fenotipicamente mestiça, tem 51 anos de idade e 16 de docência; leciona em um curso da grande área das ciências sociais aplicadas em uma instituição pública de ensino. Sua família, de classe baixa, via no estudo uma possibilidade para modificação de sua condição sóciorracial. A participante relata que sua mãe: "[...] sempre disse que a gente deveria estudar, sem limite de espaço, sem nada; então a gente foi mais ou menos criados dentro de um perfil de que o estudo era uma coisa muito importante". 
A família, como grupo primário, é considerada matriz da subjetividade e tem papel fundamental na formação da identidade de Pollyanna. Por causa da influência familiar, o estudo adquire um sentido emancipatório em toda a sua trajetória. Durante o ensino fundamental e médio, escutou como bolsista em uma escola particular. Ela lembra: "uma sala de aula, sem negros [...]".

Quando ingressou no curso superior de uma instituição pública, também percebeu que não havia representatividade:

Eu me lembro demais que eu cheguei na cantina, olhei assim, falei: "Nossa!" pra minha amiga loira dos olhos azuis, "Nossa! Não tem um negro aqui. Por quê?", por que na minha sala, que tinha 55 alunos, só tinha eu e mais uma menina.

Segundo Piza (2002), a raça é algo evidenciado apenas no negro, enquanto ao branco é colocada uma posição de neutralidade:

Um negro representa todos os negros. Um branco é uma unidade representativa apenas de si mesmo. Não se trata da invisibilidade da cor, mas da intensa visibilidade da cor e de outros traços fenotípicos aliados a estereotípicos sociais e morais, para uns, e a neutralidade racial, para outros. (p. 72)

Em busca de estabilidade financeira, Pollyanna fez concurso público para trabalhar como técnica, porém, depois de algum tempo, foi acometida de uma forte crise depressiva, época na qual fez tratamento psiquiátrico e psicológico.

"Lá a gente descobriu essa coisa de eu ter muita energia e querer fazer muita coisa, de estar muito parada nesse serviço mecânico. Foi o momento que eu descobri que queria fazer mestrado".

O trabalho mecanicista era algo que não fazia parte da identidade de Pollyanna. A reposição (mesmice) do papel era uma situação imposta na qual ela não via saídas, o que a angustiava e oprimia. Ciampa (2003) chama esse fenômeno de "fetiche da personagem, quando continuamos repondo algo que já não somos (como atividade real), freqüentemente (sic) uma compulsão à repetição" (p. 7). A terapia, por meio da ação comunicativa, proporcionou atribuir novos sentidos em sua vida, mais libertadores e menos opressivos. Após terminar seu mestrado, foi convidada a lecionar numa instituição de ensino privada: "Fui a primeira professora do [instituição privada], que entrou na sala de [curso] [...] Eu me 
apaixonei pela docência: - Bom, é isso que eu quero fazer e agora eu tenho que correr atrás de fazer um doutorado".

$\mathrm{O}$ ato de lecionar foi dotado de um poder inovador e criador de novos sentidos para sua existência. Foi significado de superação de condições pessoais e sociais que a impediam de participar na decisão de suas próprias ações.

Após seu doutoramento, ela tentou entrar em uma instituição de ensino pública por meio de concurso, o que foi concretizado na segunda tentativa. A carreira de profissionais acadêmicos e sua promessa de liberdade e status exercem certo encantamento na sociedade, pois, nesse ambiente, é julgado haver respeito às desigualdades, além da estabilidade financeira de um serviço público (Miranda, 2013).

Pollyanna nos mostra fragmentos de emancipação ao se encontrar na carreira acadêmica, porém, a emancipação não é um processo contínuo e pleno. O sistema capitalista no qual o capital é o sujeito (Ciampa, 1984) ainda nos aliena, e com ela não é diferente. Por sempre frequentar lugares hegemonicamente brancos, logo interiorizou os padrões de beleza eurocêntricos, utilizando sempre o cabelo liso: "Meu cabelo é escovado e relaxado; eu não consigo mantê-lo natural, o afro, não consigo. Eu me vejo assim [com o cabelo alisado]".

A mudança no corpo não é puramente estética, mas se amplia ao âmbito identitário e político do sujeito, ao rejeitar uma característica própria e aderir outra que oculta traços de seu pertencimento racial (Miranda, $2011 \mathrm{~b}$ ).

O sujeito é formado pela força da exclusão e da abjeção, determinando um exterior constitutivo e que constitui seu próprio repúdio, sem o qual não pode emergir. É "[...] o social que atua unilateralmente sobre o natural e o investe com seus parâmetros e significados" (Butler, 2007, p. 156). A abjeção é como um espectro ameaçador

Eu não me vejo como eu sou; tem isso, entendeu? Eu lembro que uma vez eu estava [em uma capital brasileira] e, interessantíssimo, aí eu entrei numa loja, aí tinha um espelho assim e quando, sabe quando você olha? E eu levei um susto, por quê? Sabe essa coisa de, não sei, pra mim essa não é a minha, esse corpo não é meu corpo, ele não é assim. 
Seu corpo não faz sentido nem para si mesma; ela não o reconhece em seu próprio reflexo. A desfragmentação desse corpo é um efeito da dinâmica do poder, de tal modo que a matéria do corpo como um todo se torna inseparável das normas hegemônicas que imperam sobre a sua materialização. Essa zona de inabitalidade é produzida através do repúdio de um significante primário, constituindo uma zona inóspita para o sujeito, reiterando a abjeção adjudicada pela sociedade (Butler, 2007).

Quando questionamos sobre suas projeções para o futuro: "Eu queria ter uma ONG assim, sabe, eu acho muito legal. Se eu tivesse condições de bancar uma coisa dessa, eu te diria que a minha perspectiva é essa".

Ela relata ter o desejo de administrar uma casa que assistisse gratuitamente pessoas sem condições de pagar profissionais como médicos, dentistas, psicólogos, entre outros. Segundo Ciampa (2002), cada indivíduo participa de muitas psiques de massa, ao mesmo tempo, como a de sua raça, de sua classe, de sua religiosidade, cidadania; e pode ainda construir-se com uma parcela de autonomia e originalidade. Não negamos que esse projeto possa ser um fragmento de emancipação baseado na solidariedade, mas analisamos como algo ainda estruturado em uma ideia assistencialista, capturada pelos ditames hegemônicos.

\section{Conclusões: três mulheres, três histórias e a luta contra um mesmo sistema de opressões}

Três mulheres negras que se tornaram professoras universitárias; três professoras que se ocultaram em alguns aspectos identitários, mas se revelaram em algumas partes de suas histórias; três histórias que se diferenciam em suas singularidades e momentos históricos, mas se assemelham em alguns aspectos por vivenciarem um mesmo sistema opressor: o sistema que oprime mulheres, negros, pobres, e todos aqueles que não dizem de uma hegemonia. Segundo Crenshaw (2002), por estarmos inseridos em um contexto onde forças econômicas, culturais e sociais moldam em silêncio um pano de fundo no qual as mulheres são constantemente afetadas por outras normas de subordinação, a discriminação interseccional é particularmente difícil de ser reconhecida. Ainda segundo a 
mesma autora, "por ser tão comum, a ponto de parecer um fato da vida, natural ou pelo menos imutável, esse pano de fundo (estrutural) é, muitas vezes, invisível" (p. 176).

Essas mulheres (e tantas outras) existem sob o signo do capitalismo e a constante complexidade da sociedade moderna, obstadas de serem verdadeiramente sujeitos de suas histórias. O capitalismo nega a humanidade a essas mulheres, pois sua inclinação é sujeitálas como mero suporte do capital, ou seja, reificá-las. No entanto, a identidade se apresenta como um horizonte de possibilidades, e cada uma delas significa de forma diferente seus fragmentos de emancipação de acordo com suas histórias de vida. A própria escolha profissional diz de um projeto político: ser professora negra é um ofício que pode possibilitar a aceitabilidade de seus proferimentos, não só como sujeito individual, mas como parte representativa de uma minoria social. O corpo da mulher e da mulher negra na academia diz de uma resistência política diante de um universo de obstáculos que se interseccionam: ser mulher, negra e, muitas vezes, de origem pobre no contexto acadêmico requer coragem e uma luta constante pelo reconhecimento. É claro que em toda regra há exceções, mas, nas três entrevistas, lecionar é uma atividade que, apesar das dificuldades, tornou-se projeto de vida, que interceptado por ações e objetivos mais amplos, também se constitui para essas mulheres um projeto político. Por sua vez, todo projeto político que se pretende ético não consiste em observar a história de forma estática, mas atuar como agente transformador em projetos que promovam um futuro a ser feito coletivamente, visando à transformação social (Ciampa, 1984).

\section{Referências}

Arboleya, A., Ciello, F., \& Meucci, S. (2015). "Educação para uma vida melhor": trajetórias sociais de docentes negros. Cadernos de Pesquisa, 45(158), 882-914. http://doi.org/10.1590/198053143248 
Butler, J. (2007). Corpos que pesam: sobre os limites discursivos do "sexo". In G. L. Louro (Org.), O corpoeducado: pedagogias da sexualidade (2a ed., pp. 151-172). Belo Horizonte: Autêntica.

Carone, I. (s.d.). Análise epistemológica da tese de doutoramento de Antonio da Costa Ciampa. (Mimeo).

Carvalho, J. J. (2006). O confinamento racial do mundo acadêmico brasileiro. Revista USP, (68), 88-103. https://doi.org/10.11606/issn.2316-9036.v0i68p88-103

Ciampa, A. C. (1984). Identidade. In S. T. M. Lane (Org.), Psicologia Social: o homem em movimento (pp. 58-75). São Paulo: Editora Brasiliense.

Ciampa, A. C. (1987). A estória do Severino e a história da Severina. São Paulo: Editora Brasiliense.

Ciampa, A. C. (1999). Identidade: um paradigma para a Psicologia Social? Anais $X$ Encontro Nacional da Associação Brasileira de Psicologia Social - ABRAPSO (pp. 1-5). São Paulo: ABRAPSO. (Texto provisório para divulgação interna)

Ciampa, A. C. (2002). Políticas de identidade e identidades políticas. In C. L. I. Dunker, \& M. C. Passos (Eds.), Uma psicologia que se interroga: ensaios (pp. 133-144). São Paulo: Edicon.

Ciampa, A. C. (2003). A identidade social como metamorfose humana em busca de emancipação: articulando pensamento histórico e pensamento utópico. Anais XXIX Congresso Interamericano de Psicologia (pp. 1-2). Lima: CIP.

Crenshaw, K. (2002). Documento para o encontro de especialistas em aspectos da discriminação racial relativos ao gênero. Revista estudos feministas, 10(1), 171-188. http://doi.org/10.1590/S0104-026X2002000100011 
Ferreira, R. F. (2002). O Brasileiro, o racismo silencioso e emancipação do afrodescendente. Psicologia \& Sociedade, 14(1), 69-86. $\quad$ http://doi.org/10.1590/S0102$\underline{71822002000100005}$

Fry, P. H. (2002). Política, nacionalidade e o significado da "raça" no Brasil. In L. Bethel (Org.), Brasil: fardo do passado, promessa do futuro (pp. 153-202). Rio de Janeiro: Civilização Brasileira.

Habermas, J. (1987). A nova intransparência: a crise do estado de bem estar social e o esgotamento das energias utópicas. Novos Estudos CEBRAP, (18), 103-114.

Haraway, D. (1995). Saberes localizados: a questão da ciência para o feminismo e o privilégio da perspectiva parcial. Cadernos Pagu, (5), 7-41. $\underline{\text { https://periodicos.sbu.unicamp.br/ojs/index.php/cadpagu/article/view/1773 }}$

Hooks, B. (1995). Intelectuais Negras. Revista Estudos Feministas, 3(2), 454-478. https://doi.org/10.1590/\%25x

Kolyniak, H. M. R. (2005). Uma abordagem psicossocial de corporeidade e identidade. Revista Integração, 43, 337-345. http://ftp.usjt.br/pub/revint/337_43.pdf

Lima, A. A. (2001). Legitimação do intelectual negro no meio acadêmico brasileiro: Negação de inferioridade, confronto ou assimilação intelectual. Afro-Ásia, (25-26), 281-312. http://doi.org/10.9771/aa.v0i25-26.21015

Louro, G. L. (2001). Teoria queer: uma política pós-identitária para a educação. Revista Estudos Feministas, 9(2), 541-553. $\quad$ https://doi.org/10.1590/S0104$\underline{026 \times 2001000200012}$

Marcondes, M. M. (2013). Dossiê mulheres negras: retrato das condições de vida das $\begin{array}{lllll}\text { mulheres negras } & \text { no Brasilia: }\end{array}$ http://www.ipea.gov.br/portal/images/stories/PDFs/livros/livros/livro_dossie_mulhere $\underline{\text { s_negras.pdf }}$ 
Meihy, J. C. S. B. (1996). Manual de história oral. São Paulo: Edições Loyola.

Miranda, S. F. (2011a). Identidades de Afro-descendentes: resistência e preconceito como motores de um processo em produção. Recife: ABRAPSO.

Miranda, S. F. (2011b). O "feio e o belo": reflexões sobre os efeitos de uma ideologia do corpo. Psicologia para América Latina, (22), 1-8. http://pepsic.bvsalud.org/pdf/psilat/n22/a04.pdf

Miranda, S. F. (2013). Negros, profissionais e acadêmicos: sentidos identitários e os efeitos do discurso ideológico do mérito [Tese de Doutorado, Pontifícia Universidade Católica de São Paulo].

Miranda, S. F. (2014). Identidade sob a perspectiva da psicologia Social Crítica: revisitando os caminhos da edificação de uma teoria. Revista de Psicologia, 5(2), 124-137. http://www.periodicos.ufc.br/psicologiaufc/article/view/1481

Munanga, K. (2004). Rediscutindo a mestiçagem no Brasil: identidade nacional versus identidade negra. Belo Horizonte: Autêntica.

Pires, M. F. C. (2014). Docentes negros na universidade pública brasileira [Tese de Doutorado, Universidade Estadual de Campinas]. Repositório da Produção Científica e Intelectual da UNICAMP. http://repositorio.unicamp.br/jspui/handle/REPOSIP/253910

Piza, E. (2002). Porta de vidro: entrada para a Branquitude. In I. Carone, \& M. A. Bento (Orgs.), Psicologia Social do Racismo: estudos sobre branquitude e branqueamento no Brasil (pp. 59-90). Petrópolis: Vozes.

Pollak, M. (1989). Memória, esquecimento, silêncio. Estudos Históricos, 2(3), 3-15. http://www.uel.br/cch/cdph/arqtxt/Memoria_esquecimento_silencio.pdf

Santos, T. J. C. (2003). Trajetórias de professores universitários negros em Mato Grosso [Dissertação de Mestrado, Universidade Federal do Mato Grosso]. Repositório Institucional da Universidade Federal do Mato Grosso. 
Scott, J. W. (1995) Gênero: uma categoria útil para análise histórica. Educação \& Realidade, 20(2), 71-99. https://seer.ufrgs.br/educacaoerealidade/article/view/71721/40667

Souza, N. S. (1983). Tornar-se negro ou as vicissitudes da identidade do negro brasileiro em ascensão social. Rio de Janeiro: Graal.

Recebido em: 20/6/2018

Aprovado em: 18/12/2018 